\title{
Effects of Biochar on Properties of Tropical Sandy Soils Under Organic Agriculture
}

\author{
Nattaporn Prakongkep ${ }^{1}$, Robert J. Gilkes ${ }^{2}$, Worachart Wisawapipat ${ }^{3}$, Parapond Leksungnoen ${ }^{3}$, \\ Chanida Kerdchana ${ }^{1}$, Tawatchai Inboonchuay ${ }^{4}$, Evelyne Delbos ${ }^{5}$, Laura-Jane Strachan ${ }^{5}$, Potchara Ariyasakul ${ }^{1}$, \\ Channarong Ketdan ${ }^{1} \&$ Claude Hammecker ${ }^{6}$ \\ ${ }^{1}$ Land Development Department, Chatuchak, Bangkok, Thailand \\ 2 The University of Western Australia, Crawley, WA, Australia \\ 3 Department of Soil Science, Faculty of Agriculture, Bangkhen Campus, Kasetsart University, Bangkok, \\ Thailand \\ ${ }^{4}$ Department of Soil Science, Faculty of Agriculture, Kampheng Saen Campus, Kasetsart University, Nakhon \\ Pathom, Thailand \\ ${ }^{5}$ The James Hutton Institute, Aberdeen, Scotland \\ ${ }^{6}$ Institut de Recherche pour le Développement, Montpellier, France \\ Correspondence: Nattaporn Prakongkep, Land Development Department, 2003/61 Ladyao, Chatuchak, Bangkok, \\ 10900, Thailand. Tel: 66-86-348-1636. E-mail: asoil@hotmail.com; nattaporn@1dd.go.th
}

Received: October 31, 2020

Accepted: November 5, 2020

Online Published: December 15, 2020

doi:10.5539/jas.v13n1p1

URL: https://doi.org/10.5539/jas.v13n1p1

The research is financed by Land Development Department (LDD) and Agricultural Research Development Agency (ARDA).

\begin{abstract}
This study evaluated the influences of biochar made from local agricultural wastes on sandy soils in farmer fields where biochar has been used as a soil amendment for more than three years. The major objective of this study was to gain insight into the effects of long-term biochar application on properties of sandy soil.

Unamended soil properties were compared to biochar-amended soils properties using the paired samples t-test ( $p$ $<0.05$ ). The statistical results of the study indicated that cation exchange capacity, exchangeable potassium, available phosphorus, field capacity, plant available water, water-stable aggregate size fractions $(>1$ and $<0.25$ $\mathrm{mm}$ ), median aggregate size and aggregate stability were significantly different at $\mathrm{p}<0.05$. Clearly, biochar present for 3 or more years can improve soil physicochemical properties.

We conclude that sandy soil properties, especially soil physical properties, are very strongly affected by biochar application combined with conservative soil management. Biochars affect both physical and biological mechanisms of soil aggregate formation because the biochar particle sizes influence the arrangement of clay on biochar and biochar grains provide a favorable microbial habitat and food source for fungi creating microorganism-biochar-soil associations which enhance water-stable aggregates and water holding capacity.
\end{abstract}

Keywords: biochar application, long term, soil physicochemical properties, sandy soils

\section{Introduction}

Sandy soils are widely distributed across the world covering approximately 4,990,200,000 ha, accounting for $31 \%$ of the total land area (Huang \& Hartemink, 2020). As world population is increasing rapidly, sandy soils are being increasingly used for food production. Physical properties of sandy soils (e.g., bulk density, porosity, aggregation) vary considerably because of the size and organization of the grains, type of clay, natural processes such as biological activities or human activities and soil management (Bruand et al., 2005). Sandy soils usually have a single grained structure and poor physical properties which result in a low water-holding capacity (Andry et al., 2009; Huang \& Hartemink, 2020). Their properties restrict plant growth and local economic development 
(Zhou et al., 2016) as they have a coarse texture, little or no composite soil structure and low values of cation exchange capacity, base saturation, organic carbon concentration and fertility (Huang \& Hartemink, 2020).

The carbon content of tropical soils especially sandy soils declines substantially under intensive agriculture (Mekuria \& Noble, 2013). Land use intensity and soil management strongly affect soil organic carbon content and soil aggregate stability (Spohn \& Giani, 2011). Maintaining the long-term aggregate stability of soil by applying fresh organic residues is difficult in high temperature tropical regions because of the rapid decomposition of fresh organic residues. These are the conditions where more stable biochar can provide a soil management solution (Hseu et al., 2014).

Biochar is the product of pyrolysis of organic materials in the absence of oxygen and at high temperature. Biochar can be used for increasing sustainable soil carbon as it contains stable carbon which remains sequestered for a long period of time. Recent studies have shown that biochar not only increases soil carbon, it also improves soil structure and soil functions for sandy soils. It also supplies plant nutrients because biochar contains several essential elements (Abujabhah et al., 2016; Sorrenti \& Toselli, 2016). When biomass is heated in kilns, water in plant cells evaporates and mineral compounds are precipitated within the relic plant structure. The nutrients added in biochar result in higher plant nutrient availability (Lehmann et al., 2003). For these reasons, biochar has been considered as a suitable soil amendment for improving soil physicochemical properties, of degraded and sandy soils in subtropical and tropical regions (Chan et al., 2007; Hseu et al., 2014).

Many studies report that biochar improved both chemical (e.g., $\mathrm{pH}$, cation exchange capacity) and physical soil properties (e.g., bulk density, water holding capacity) of soils (Glaser et al., 2002; Lehmann, 2007; Jeffery et al., 2011; Hseu et al., 2014; Yadav et al., 2018). Baiamonte et al. (2015) has indicated that the application of biochar to soil improves soil structure, increases porosity, decreases bulk density, and enhances aggregation and water retention in acidic, degraded and sandy soils (Jeffery et al., 2011; Crane-Droesch et al., 2013). Some farmers have used biochar as a soil amendment for sandy soils; however, the beneficial effects of long-term field scale biochar application are quite poorly understood, especially effects on soil physical properties such as soil aggregation (Blanco-Canqui, 2017). Additional studies are needed to evaluate the long-term effects of biochar on the physical, chemical, and biological properties of sandy soils (Huang \& Hartemink, 2020). In particular the role of biochar in sustainable organic agriculture has not been clearly established. To obtain a comprehensive evaluation of biochar effects on soil properties, long-term studies (more than 1 year) should be conducted. In this study we investigated the long-term ( $>3$ years) effects of biochar application on aggregation in sandy soils and changes in other soil properties for sites under organic agricultural management in Thailand.

\section{Method}

\subsection{Soil and Biochar}

Soil samples at depths of $0-20 \mathrm{~cm}$ were collected from four farmer fields in Thailand (Table 1) where various biochars had been used as soil amendments for more than three years (Table 2). Farmers at each location practice organic agriculture with no use of chemical fertilizers or ameliorants. At Chainat and Chonburi, vegetables were grown with minimal cultivation. Chainat's vegetable gardener uses raised beds whereas at other locations the dominant land use is growing fruit and other trees such as para rubber (Table 1). Green manure and other agricultural wastes were returned to the soils. Unamended soil (control) and biochar-amended soil were collected at the same location. Two types of soil samples were collected including disturbed and undisturbed soil samples. Disturbed soil samples were homogenized, air dried and crushed to pass through a screen ( $2 \mathrm{~mm}$-opening) for chemical analysis. Additionally, undisturbed samples were collected for micromorphology (kubiena box) and physical (core sampler) analysis. The eight biochars used on these plots had been prepared by farmers using local materials and technology (carbonization temp.ca. $400{ }^{\circ} \mathrm{C}$ ). Biochar types and rates applied to soils are shown in Table 2 with total of about 100 ton per ha being applied over periods up to 10 years.

Table 1. Land use and location of studied sites

\begin{tabular}{llll}
\hline Province & Land use & Latitude & Longitude \\
\hline Chainat & Vegetable & $14^{\circ} 58^{\prime} 41.23^{\prime \prime} \mathrm{N}$ & $99^{\circ} 48^{\prime} 30.05^{\prime \prime} \mathrm{E}$ \\
Chonburi & Organic farming, Forest & $13^{\circ} 21^{\prime} 16.29^{\prime \prime} \mathrm{N}$ & $101^{\circ} 8^{\prime} 9.65^{\prime \prime} \mathrm{E}$ \\
Khon Kean & Para rubber & $16^{\circ} 32^{\prime} 37.86^{\prime \prime} \mathrm{N}$ & $102^{\circ} 5^{\prime} 58.65^{\prime \prime} \mathrm{E}$ \\
Phetchaburi & Banana, Fruit & $12^{\circ} 41^{\prime} 49.79^{\prime \prime} \mathrm{N}$ & $99^{\circ} 54^{\prime} 14.22^{\prime \prime} \mathrm{E}$ \\
\hline
\end{tabular}


Table 2. Years of use, major used biochars and rates of biochar application

\begin{tabular}{llll}
\hline Province & Years & Used biochars & Approximate biochar application rate $\left(\mathrm{t} \mathrm{ha}^{-1} \mathrm{year}^{-1}\right)$ \\
\hline Chainat & 5 & Rice husk & 15 \\
Chonburi & 10 & Siamese neem wood, Bamboo wood & 10 \\
Khon Kean & 3 & Eucalyptus wood, Burma padauk wood & 20 \\
Phetchaburi & 7 & Sweet Acacia wood, Sweet corn, Durian shell & 10 \\
\hline
\end{tabular}

\subsection{Chemical Properties of Soils and Biochars}

Soil samples were analysed according to methods used by Burt (2004). Soil pH and electrical conductivity (EC) of soils and biochar were measured in 1:1 and 1:5 soil:water extracts, respectively (Tables 3 and 7). Organic matter in soils was the organic carbon determined by the Walkley and Black wet oxidation method whereas total organic carbon was measured by combustion (Table 7). Total nitrogen in soils was determined by the Kjeldahl method. Cation exchange capacity of soils was measured by saturating the exchange sites with $1 \mathrm{M} \mathrm{NH}_{4} \mathrm{OAc}$ at $\mathrm{pH} 7.0$ and displacing $\mathrm{NH}_{4}{ }^{+}$with $10 \%$ acidified $\mathrm{NaCl}$. Available phosphorus in soils was determined by the Bray II method.

Biochar $\mathrm{pH}$ and electrical conductivity (EC) were measured using a 1:5 biochar:MilliQ (MQ) water extraction with shaking end-over-end for $12 \mathrm{hr}$. The ash content of biochars was determined by dry combustion in a ventilated muffle furnace at $600{ }^{\circ} \mathrm{C}$ overnight (Table 3). Total element concentrations in biochar were determined by digesting biochar ash in $10 \% \mathrm{HCl}$ with analysis of the solution by ICP-OES (Table 4 ). The total water soluble elements in biochar were determined by extracting the biochar with $\mathrm{MQ}$ water $(0.3 \mathrm{~g}$ biochar per $10 \mathrm{~mL} \mathrm{MQ}$ water) and shaking end-over-end for $12 \mathrm{~h}$ (Table 5). The extracts were analysed by ICP-OES. The proportion of elements soluble in water is listed in Table 6.

Table 3. Chemical properties of biochars

\begin{tabular}{llll}
\hline Biochar type/source & Ash $(\%)$ & $\mathrm{pH} 1: 5$ & $\mathrm{EC} 1: 5\left(\mathrm{mS} \mathrm{m}^{-1}\right)$ \\
\hline 1. Bamboo wood (Chonburi) & 8 & 7.8 & 0.8 \\
2. Burma padauk wood (Khon Kaen) & 3 & 7.6 & 0.1 \\
3. Eucalyptus wood (Khon Kaen) & 11 & 7.6 & 0.1 \\
4. Siamese neem wood (Chonburi) & 8 & 10.1 & 1.1 \\
5. Sweet Acacia wood (Petchaburi) & 3 & 9.6 & 0.4 \\
6. Rice husk (Chainat) & 33 & 7.3 & 1.1 \\
7. Durian shell (Petchaburi) & 17 & 10.2 & 4.0 \\
8. Sweet corn (Petchaburi) & 6 & 6.8 & 0.2 \\
\hline
\end{tabular}

Table 4. Total elemental concentrations of biochars

\begin{tabular}{llllllllll}
\hline \multirow{2}{*}{ Biochar type/source } & \multicolumn{9}{c}{ Aqua regia $\left(\mathrm{mg} \mathrm{kg}^{-1}\right)$} \\
\cline { 2 - 10 } & $\mathrm{Al}$ & $\mathrm{Ca}$ & $\mathrm{Cu}$ & $\mathrm{Fe}$ & $\mathrm{K}$ & $\mathrm{Mn}$ & $\mathrm{Mg}$ & $\mathrm{Na}$ & $\mathrm{P}$ \\
\hline 1. Bamboo wood (Chonburi) & 374 & 2,470 & 7 & 879 & 6,362 & 155 & 1,858 & 266 & 2,996 \\
2. Burma padauk wood (Khon Kaen) & 18 & 6,249 & 2 & 24 & 229 & 108 & 381 & 71 & 84 \\
3. Eucalyptus wood (Khon Kaen) & 420 & 5,769 & 10 & 731 & 657 & 68 & 389 & 661 & 346 \\
4. Siamese neem wood (Chonburi) & 36 & 3,961 & 7 & 64 & 14,581 & 11 & 284 & 236 & 2,027 \\
5. Sweet acacia wood (Petchaburi) & 30 & 13,646 & 5 & 32 & 2,951 & 46 & 352 & 654 & 201 \\
6. Rice husk (Chainat) & 199 & 1,771 & 7 & 496 & 7,761 & 282 & 810 & 250 & 835 \\
7. Durian shell (Petchaburi) & 494 & 8,603 & 27 & 756 & 52,573 & 81 & 7,723 & 448 & 4,941 \\
8. Sweet corn (Petchaburi) & 30 & 217 & 31 & 95 & 13,598 & 14 & 2,844 & 102 & 6,954 \\
\hline
\end{tabular}


Table 5. Concentrations of water-soluble elements in biochars

\begin{tabular}{|c|c|c|c|c|c|c|c|c|c|}
\hline \multirow{2}{*}{ Biochar type/source } & \multicolumn{9}{|c|}{ Water soluble $\left(\mathrm{mg} \mathrm{kg}^{-1}\right)$} \\
\hline & $\mathrm{Al}$ & $\mathrm{Ca}$ & $\mathrm{Cu}$ & $\mathrm{Fe}$ & $\mathrm{K}$ & $\mathrm{Mn}$ & $\mathrm{Mg}$ & $\mathrm{Na}$ & $\mathrm{P}$ \\
\hline 1. Bamboo wood (Chonburi) & 3.0 & 411 & 0.1 & 0.2 & 2,880 & 7.4 & 865 & 245 & 1,570 \\
\hline 2. Burma padauk wood (Khon Kaen) & 4.5 & 1,393 & nd & 0.8 & 30 & 2.1 & 92 & 19 & nd \\
\hline 3. Eucalyptus wood (Khon Kaen) & 4.6 & 336 & 0.2 & 0.5 & 90 & 0.6 & 35 & 318 & nd \\
\hline 4. Siamese neem wood (Chonburi) & 9.0 & 288 & 0.4 & 0.7 & 11,488 & nd & 114 & 138 & 928 \\
\hline 5. Sweet Acacia wood (Petchaburi) & 6.7 & 797 & nd & 1.3 & 2,872 & 0.1 & 52 & 382 & nd \\
\hline 6. Rice husk (Chainat) & 8.3 & 287 & 1.1 & 7.6 & 4,848 & 24.9 & 183 & 154 & 434 \\
\hline 7. Durian shell (Petchaburi) & 15.3 & 650 & 5.2 & 25.4 & 44,914 & 3.2 & 729 & 380 & 4,179 \\
\hline 8. Sweet corn (Petchaburi) & 4.9 & 107 & 0.7 & 14.9 & 5,876 & 4.0 & 1,444 & 48 & 4,063 \\
\hline
\end{tabular}

Note. nd $=$ non detected.

Table 6 . The proportion of the total element content in biochar that is water soluble

\begin{tabular}{llllllllll}
\hline Biochar type/source & $\mathrm{Al}$ & $\mathrm{Ca}$ & $\mathrm{Cu}$ & $\mathrm{Fe}$ & $\mathrm{K}$ & $\mathrm{Mn}$ & $\mathrm{Mg}$ & $\mathrm{Na}$ & $\mathrm{P}$ \\
\hline 1. Bamboo wood (Chonburi) & 0.01 & 0.17 & 0.01 & 0.00 & 0.45 & 0.05 & 0.47 & 0.92 & 0.52 \\
2. Burma padauk wood (Khon Kaen) & 0.25 & 0.22 & 0.00 & 0.03 & 0.13 & 0.02 & 0.24 & 0.27 & 0.01 \\
3. Eucalyptus wood (Khon Kaen) & 0.01 & 0.06 & 0.02 & 0.00 & 0.14 & 0.01 & 0.09 & 0.48 & 0.00 \\
4. Siamese neem wood (Chonburi) & 0.25 & 0.07 & 0.06 & 0.01 & 0.79 & 0.00 & 0.40 & 0.58 & 0.46 \\
5. Sweet Acacia wood (Petchaburi) & 0.22 & 0.06 & 0.00 & 0.04 & 0.97 & 0.00 & 0.15 & 0.58 & 0.02 \\
6. Rice husk (Chainat) & 0.04 & 0.16 & 0.16 & 0.02 & 0.62 & 0.09 & 0.23 & 0.62 & 0.52 \\
7. Durian shell (Petchaburi) & 0.03 & 0.08 & 0.19 & 0.03 & 0.85 & 0.04 & 0.09 & 0.85 & 0.85 \\
8. Sweet corn (Petchaburi) & 0.16 & 0.49 & 0.02 & 0.16 & 0.43 & 0.29 & 0.51 & 0.47 & 0.58 \\
\hline
\end{tabular}

Table 7. Chemical properties of the Ap-horizon of control and treated soils in the four farmer fields

\begin{tabular}{|c|c|c|c|c|c|c|c|c|c|c|c|c|}
\hline Province & Biochar treatment & $\mathrm{pH} 1: 1$ & $\mathrm{EC} 1: 5$ & $\mathrm{OM}$ & TOC & Total N & CEC & $\mathrm{Ex} \mathrm{Ca}$ & Ex K & $\mathrm{Ex} \mathrm{Mg}$ & $\mathrm{Ex} \mathrm{Na}$ & Avail P \\
\hline & & & $\mathrm{mS} \mathrm{m}^{-1}$ & \multicolumn{3}{|c|}{--------- \% --------- } & \multicolumn{5}{|c|}{---------------- $\mathrm{cmol} \mathrm{kg}^{-1}$--------------- } & $\mathrm{mgP} \mathrm{kg}{ }^{-1}$ \\
\hline Chainat & Control & 7.4 & 0.22 & 0.55 & 1.3 & 0.05 & 5.2 & 1.99 & 0.49 & 0.72 & 1.03 & 83 \\
\hline Chainat & Rice husk & 6.9 & 0.27 & 1.55 & 2.5 & 0.16 & 8.0 & 5.25 & 0.57 & 0.88 & 0.57 & 315 \\
\hline Chonburi & Control & 6.1 & 0.06 & 2.48 & 3.4 & 0.13 & 7.0 & 2.74 & 0.33 & 0.60 & 0.31 & 108 \\
\hline Chonburi & Siamese neem wood, Bamboo wood & 7.0 & 0.11 & 2.06 & 2.9 & 0.12 & 7.9 & 3.46 & 0.52 & 0.55 & 0.14 & 220 \\
\hline Khon Kean & Control & 5.9 & 0.08 & 0.17 & 1.0 & 0.10 & 1.2 & 0.24 & 0.24 & 0.07 & 0.47 & 90 \\
\hline Khon Kean & Eucalyptus wood, Burma padauk wood & 5.2 & 0.09 & 0.41 & 1.8 & 0.07 & 2.5 & 0.54 & 0.28 & 0.08 & 0.11 & 198 \\
\hline Phetchaburi & Control & 8.0 & 0.13 & 2.63 & 3.6 & 0.16 & 8.5 & 11.15 & 0.19 & 1.12 & 0.42 & 720 \\
\hline Phetchaburi & Sweet Acacia wood, Sweet corn, Durian shell & 7.8 & 0.27 & 2.71 & 3.9 & 0.16 & 9.7 & 11.37 & 0.23 & 1.30 & 0.78 & 937 \\
\hline
\end{tabular}

Note. EC = Electrical conductivity; OM = Organic matter Walkley and Black method; TOC = Total organic carbon Combustion method; Total $\mathrm{N}=$ Total nitrogen; $\mathrm{CEC}=$ Cation exchange capacity; $\mathrm{Ex} \mathrm{Ca}, \mathrm{K}, \mathrm{Mg}, \mathrm{Na}=$ Exchangeable calcium, potassium, magnesium, sodium; Avail $\mathrm{P}=$ Available phosphorus.

\subsection{Physical Properties}

Water-stable aggregates were fractionated according to Kemper and Rosenau (1986). Two core samples from control and treated soils were oven dried $\left(105^{\circ} \mathrm{C}, 48 \mathrm{~h}\right)$ and used to calculate bulk densities (Table 8). Particle size distribution was determined by the pipette method. Soil water retention was determined using a pressure plate apparatus at suctions equivalent to field capacity (FC) 1/3 atm and permanent wilting point (PWP) 15 atm. Saturated hydraulic conductivity (Ksat) measurements were obtained using a constant head method. 
Table 8. Soil physical properties of the Ap-horizon for the four farmer fields

\begin{tabular}{|c|c|c|c|c|c|c|c|c|c|}
\hline \multirow{2}{*}{ Province } & \multirow{2}{*}{ Biochar treatment } & \multirow{2}{*}{ Sand } & \multirow{2}{*}{ Silt } & \multirow{2}{*}{ Clay } & \multicolumn{3}{|c|}{ Water content ( $\%$ by weight $)$} & \multirow{2}{*}{ Bulk density } & \multirow{2}{*}{ Ksat } \\
\hline & & & & & FC 1/3 atm & PWP 15 atm & PAW & & \\
\hline & & \multicolumn{3}{|c|}{ 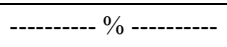 } & & & & $\mathrm{g} \mathrm{cm}^{-3}$ & $\mathrm{~cm} \mathrm{hr}^{-1}$ \\
\hline Chainat & Control & 75 & 16 & 9 & 7.7 & 2.9 & 4.8 & 1.55 & 23 \\
\hline Chainat & Rice husk & 70 & 22 & 9 & 11.3 & 4.1 & 7.2 & 1.53 & 15 \\
\hline Chonburi & Control & 83 & 14 & 3 & 9.7 & 4.0 & 5.7 & 1.28 & 62 \\
\hline Chonburi & Siamese neem wood, Bamboo wood & 81 & 15 & 4 & 11.2 & 3.8 & 7.4 & 1.28 & 62 \\
\hline Khon Kean & Control & 84 & 12 & 5 & 3.7 & 1.3 & 2.4 & 1.49 & 14 \\
\hline Khon Kean & Eucalyptus wood, Burma padauk wood & 83 & 13 & 4 & 5.0 & 1.6 & 3.4 & 1.32 & 17 \\
\hline Phetchaburi & Control & 82 & 15 & 3 & 9.6 & 3.9 & 5.7 & 1.35 & 42 \\
\hline Phetchaburi & Sweet Acacia wood, Sweet corn, Durian shell & 81 & 15 & 4 & 11.3 & 4.8 & 6.5 & 1.29 & 53 \\
\hline
\end{tabular}

Note. $\mathrm{FC}=$ Field capacity; $\mathrm{PWP}=$ Permanent wilting point, $\mathrm{PAW}=$ Plant available water.

\subsection{Micromorphology, SEM and EDS}

Kubiena boxes were used to collect undisturbed blocks of unamended and biochar-amended soils to make thin sections after impregnation with resin. Soil micromorphology was studied on thin sections of resin impregnated soils using a Leitz polarizing microscope. Thin sections of soils, original and recovered biochars from soils were used for scanning electron microscopy using a Carl Zeiss SIGMA VP fitted with an Energy Dispersive Spectrometer (EDS) for elemental analysis.

\subsection{Image Analysis}

Thin sections of the Ap-horizon of soil from each location were examined. To determine the nature of soil aggregates a Leitz polarizing microscope with plane polarized light (PPL) was used to produce optical micrographs (Figure 4a). The optical micrographs were adjusted using the Photoshop program prior to image analysis. Raw optical micrographs were converted to grayscale mode and TIFF file format with $1600 \times 1200$ pixels (Figure $4 b$ ) then the aggregate boundaries were identified. An image analysis program (ImageJ 1.52a) was used to measure the size of soil aggregates seen in optical micrographs (Cox \& Budhu, 2008). Grayscale mode images were used for automatic variable threshold (binary contrast enhancement) and the location, size and shape of biochar particles was determined by normal thresholding (Figure 4c). Soil aggregates were analysed by ImageJ following these steps: Image $>$ Adjust $>$ Threshold $>$ Analyze $>$ Analyze particles $>$ Outline $>$ Clear results. Aggregate size was obtained by measurement of major and minor axes of aggregates.

\section{$2.6 X R D$}

Compounds (minerals) in ground biochars (size $<0.05 \mathrm{~mm}$ ) were identified by X-ray diffraction analysis using an XPert ${ }^{3}$ powder diffractometer with Ni filter $(\mathrm{CuK \alpha}, 45 \mathrm{kV}, 40 \mathrm{~mA})$ and Pixel detector. Powders were scanned from 5 to $70^{\circ} 2 \theta$, using a step size of $0.015^{\circ} 2 \theta$ and a scan speed of $0.02^{\circ} 2 \theta \mathrm{s}^{-1}$.

\subsection{Statistical Analysis}

Paired samples for means t-tests in Microsoft Excel 2010 were used to compare the means of soil properties of unamended and biochar amendment treatments which were performed to determine effects of biochar on soil properties. Significant differences are given with a significance level of $\mathrm{p}<0.05$.

\section{Results}

\subsection{Biochar Characteristics}

Biochar $\mathrm{pH}$ was neutral to alkaline (6.8 to 10.2$)$ with low to moderate electrical conductivity values $(0.03$ to 4.0 $\mathrm{mS} \mathrm{m}^{-1}$ ). Ash contents were low (3 to 17\%); except for rice husk biochar (33\%) which contains much amorphous silica (Table 3, Figure 3). Mineral phases in biochar depended on the type of biomass. Calcite, sylvite and struvite were present in some biochars as has been reported by other studies (Prakongkep et al., 2015). Variations in mineral phases were related to the variable solubility of nutrient elements in biochar (Table 6 and Figure 1). All biochars have a low aluminum concentration because $\mathrm{Al}$ is not a vital element for plant tissue (Table 4); therefore, the presence of $\mathrm{Al}$ is probably due to contamination by soil clay minerals. The $\mathrm{Ca}$ concentration in sweet acacia wood biochar $\left(13,646 \mathrm{mg} \mathrm{kg}^{-1}\right)$ is higher than for other biochars (Table 4). Biochar made from the various woods contains high amounts of calcium because calcium is commonly a major element in wood (Fromm, 2010); however, the $\mathrm{Ca}$ in biochar is mostly in calcite and poorly soluble in water (Tables 5 and 6); consequently, it will dissolve slowly in soil. Copper, iron, manganese and sodium concentrations are quite low in 
all biochars. The potassium concentration of durian shell biochar is very high $\left(52,573 \mathrm{mg} \mathrm{kg}^{-1}\right)$ because $\mathrm{K}$ is essential to fruit development. This $\mathrm{K}$ is highly soluble $(85 \%)$ because the crystalline $\mathrm{K}$ mineral in durian shell biochar is struvite (Figure 1) which is soluble in water (Tables 5 and 6). Magnesium and phosphorus concentrations in fruit biochar (durian shell and sweet corn biochar) are higher than in wood and rice husk biochar and most $\mathrm{P}$ is soluble (Table 4). Scanning electron micrographs indicate minerals are present as crystals on biochar surfaces and inside pores in biochar grains (Figure 2). Extremely small $\mathrm{Ca}_{3}\left(\mathrm{PO}_{4}\right)_{2}$ crystals were present in aggregates in pores in bamboo wood biochar (Figure 2a), single crystals of sylvite are present in rice husk biochar together with abundant particles of amorphous silica. Euhedral crystals of calcite and acicular crystals of sylvite are present in siamese neem tree biochar (Figure 2c).

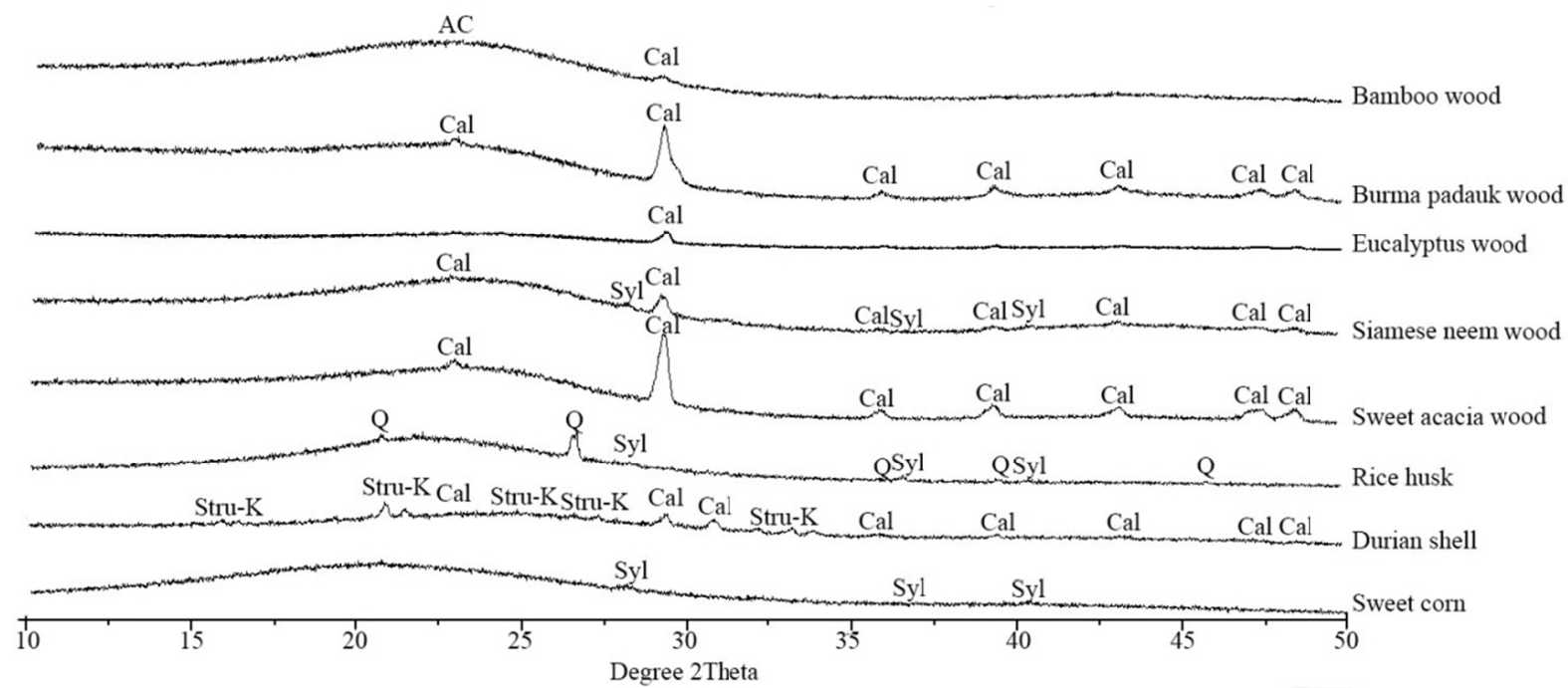

Figure 1. XRD patterns of biochars. $\mathrm{AC}=$ Amorphous carbon, $\mathrm{Cal}=\mathrm{Calcite}\left(\mathrm{CaCO}_{3}\right), \mathrm{Q}=\mathrm{Quartz}(\mathrm{SiO}), \mathrm{Syl}=$ Sylvite $(\mathrm{KCl})$ and Stru-K $=$ Struvite-K $\left(\mathrm{KMgPO}_{4} \cdot 6 \mathrm{H}_{2} \mathrm{O}\right)$ 

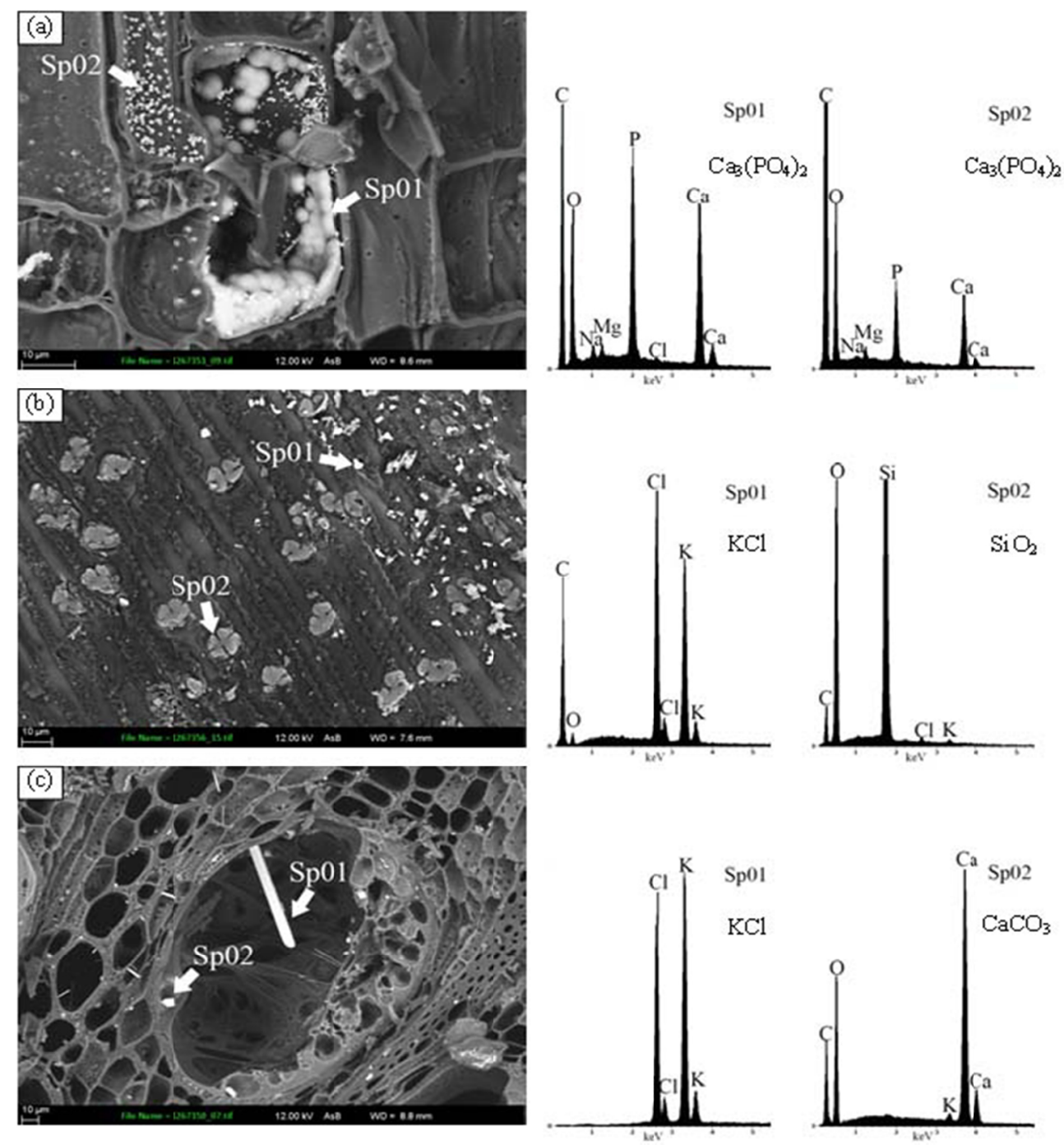

Figure 2. Scanning electron micrographs of biochars and X-ray spectra of inorganic minerals in (a) bamboo wood biochar, (b) rice husk biochar and (c) siamese neem tree wood biochar 

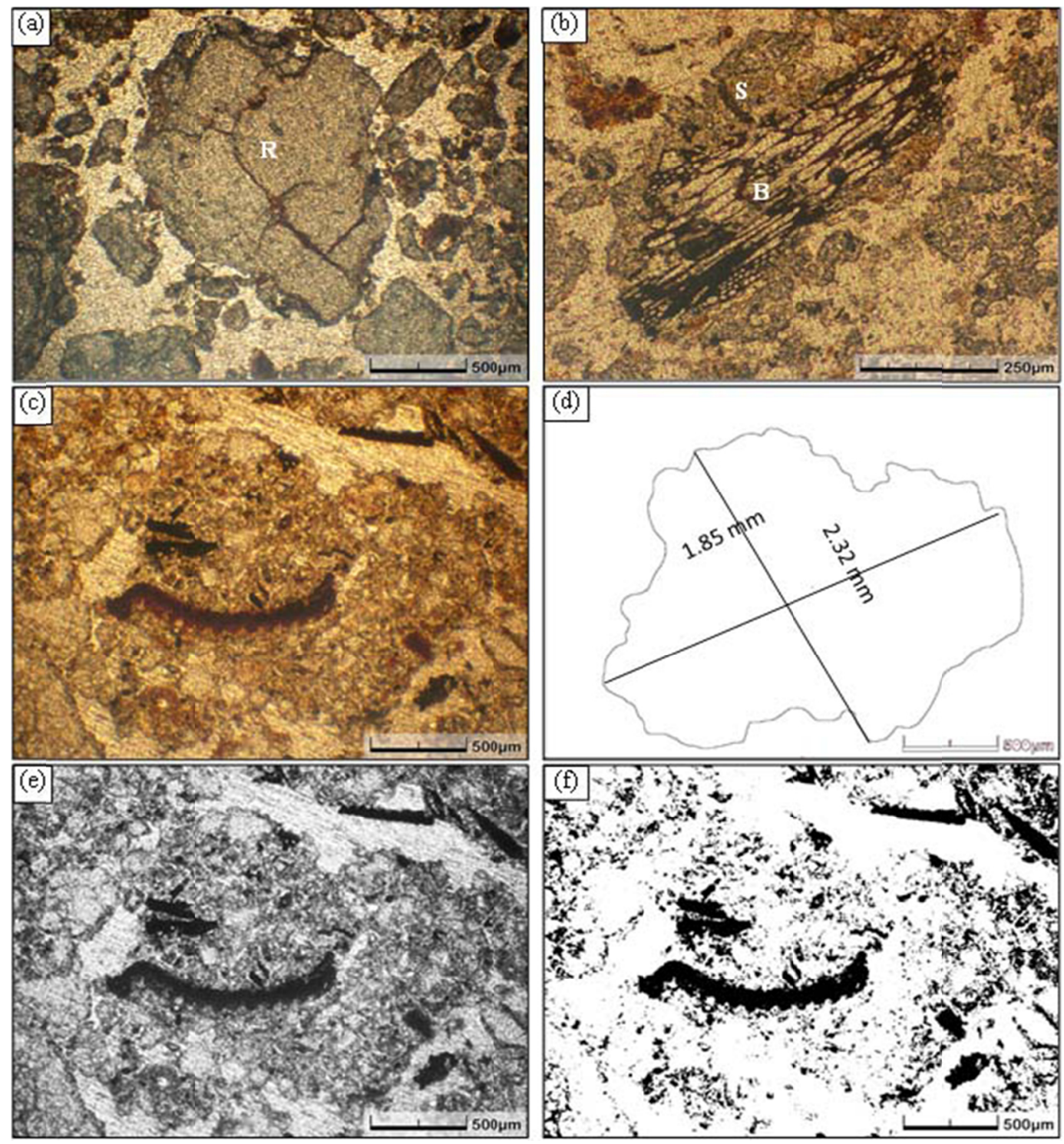

Figure 3. Optical micrographs of (a) thin sections of unamended soil showing sandy single grain microstructure including runiquartz (R); (b) biochar-amended soil showing biochar (B) attached to soil particles (S) forming a soil aggregate. Both micrographs of soil from Phetchaburi province; (c) Optical micrograph of an aggregate in a biochar amended soil for the Ap $(0-15 \mathrm{~cm})$ horizon (Chainat); (d) outline of the aggregate; (e) binary image after thresholding by the ImageJ program highlighting biochar particles and (f) binary image highlighting biochar particles

\subsection{Soil Chemical Characteristics}

All farmers have used biochar $\left(\geq 10\right.$ ton ha $\left.{ }^{-1}\right)$ as an annual soil amendment over more than 3 years. The biochars used at each location reflect the biomass available at that location (Table 2). Most sites mainly used wood biochars whereas at Chainat rice husk biochar was mostly used. Chemical properties for soils treated with these biochars are shown in Table 7. Physical properties for the treated soils are shown in Tables 8 and 9.

Biochar-amended soils do not have systematically higher organic matter, total organic carbon content or total nitrogen content than the corresponding unamended soils (Table 7). Similarly, there was no systematic increase in $\mathrm{pH}$ for biochar treated soils. Soil EC did increase slightly for biochar treated soils. Biochar-amended soils have higher $\operatorname{CEC}\left(\triangle \mathrm{CEC}=0.9\right.$ to $\left.1.3 \mathrm{cmol} \mathrm{kg}{ }^{-1}\right)$, exchangeable potassium $\left(\Delta \mathrm{Ex} . \mathrm{K}=0.04\right.$ to $\left.0.19 \mathrm{cmol} \mathrm{kg}^{-1}\right)$ and available phosphorous ( $\Delta$ avail. $\mathrm{P}=108$ to $232 \mathrm{mgP} \mathrm{kg}^{-1}$ ) than unamended soils. 
A paired t-test $(\mathrm{p}<0.05)$ was used to determine the mean scores between unamended and biochar-amended soils at each location. The results of the test are presented in Table 10 which indicate that the mean score for cation exchange capacity; exchangeable potassium and available phosphorus showed a significant difference between unamended and biochar-amended soils at $\mathrm{p}<0.05$. This observation is as same as reported by several researchers who have confirmed the beneficial effect of biochar on the soil cation exchange capacity and available phosphorous and potassium (Laird et al., 2010; Yuan et al., 2011; Fellet et al., 2011; Wang et al., 2014; Gondek et al., 2019). The higher exchangeable potassium and available phosphorus values of biochar-amended soils are due to the total potassium and phosphorus contents of biochars and the high proportion of water-soluble potassium and phosphorus in biochar (Table 6).

Table 9. Aggregate size and aggregate stability of the Ap horizon of treated soils

\begin{tabular}{|c|c|c|c|c|c|c|c|c|c|}
\hline \multirow{2}{*}{ Province } & \multirow{2}{*}{ Biochar treatment } & \multicolumn{6}{|c|}{ Water-stable aggregate-size fractions (\%) } & \multirow{2}{*}{$\begin{array}{l}\text { Median aggregate } \\
\text { size }(\mathrm{mm})\end{array}$} & \multirow{2}{*}{$\begin{array}{l}\text { Aggregate } \\
\text { Stability (\%) }\end{array}$} \\
\hline & & $>2 \mathrm{~mm}$ & $2-1 \mathrm{~mm}$ & $1-0.5 \mathrm{~mm}$ & $0.5-0.25 \mathrm{~mm}$ & $0.25-0.1 \mathrm{~mm}$ & $<0.1 \mathrm{~mm}$ & & \\
\hline Chainat & Control & 13 & 11 & 12 & 12 & 18 & 33 & 0.54 & 49 \\
\hline Chainat & Rice husk & 18 & 13 & 12 & 13 & 17 & 28 & 0.77 & 55 \\
\hline Chonburi & Control & 5 & 11 & 21 & 24 & 22 & 17 & 0.76 & 61 \\
\hline Chonburi & $\begin{array}{l}\text { Siamese neem wood, } \\
\text { Bamboo wood }\end{array}$ & 23 & 15 & 19 & 19 & 14 & 10 & 1.16 & 76 \\
\hline Khon Kean & Control & 8 & 1 & 4 & 18 & 39 & 29 & 0.30 & 32 \\
\hline Khon Kean & $\begin{array}{l}\text { Eucalyptus wood, } \\
\text { Burma padauk wood }\end{array}$ & 18 & 3 & 5 & 17 & 32 & 24 & 0.58 & 43 \\
\hline Phetchaburi & Control & 1 & 10 & 20 & 27 & 25 & 17 & 0.69 & 59 \\
\hline Phetchaburi & $\begin{array}{l}\text { Sweet Acacia wood, } \\
\text { Sweet corn, Durian shell }\end{array}$ & 41 & 15 & 16 & 13 & 9 & 7 & 1.67 & 84 \\
\hline
\end{tabular}

Table 10. Paired sample t-test for chemical properties of unamended and biochar-amended soils

\begin{tabular}{|c|c|c|c|c|c|c|}
\hline \multirow{3}{*}{ Parameter } & \multicolumn{4}{|c|}{ Paired differences } & \multirow{3}{*}{$\mathrm{t}$} & \multirow{3}{*}{$\mathrm{P}$} \\
\hline & \multicolumn{2}{|c|}{ Unamended soil } & \multicolumn{2}{|c|}{ Biochar-amended soil } & & \\
\hline & $\bar{X}$ & S.D. & $\bar{X}$ & S.D. & & \\
\hline $\mathrm{pH} 1: 5$ & 6.85 & 1.03 & 6.73 & 1.20 & 0.35 & 0.37 \\
\hline $\mathrm{EC} 1: 5\left(\mathrm{mS} \mathrm{m}^{-1}\right)$ & 0.12 & 0.01 & 0.19 & 0.01 & -2.27 & 0.054 \\
\hline $\mathrm{OM}(\%)$ & 1.46 & 1.63 & 1.68 & 0.95 & -0.77 & 0.25 \\
\hline TOC (\%) & 2.33 & 1.86 & 2.78 & 0.77 & -1.23 & 0.15 \\
\hline Total N (\%) & 0.11 & 0.002 & 0.13 & 0.002 & -0.56 & 0.31 \\
\hline $\mathrm{CEC}\left(\mathrm{cmol} \mathrm{kg}{ }^{-1}\right)$ & 5.48 & 9.94 & 7.03 & 9.78 & -3.64 & $0.018^{*}$ \\
\hline $\mathrm{Ex} \mathrm{Ca}\left(\mathrm{cmol} \mathrm{kg}^{-1}\right)$ & 4.03 & 23.63 & 5.16 & 20.94 & -1.56 & 0.11 \\
\hline $\operatorname{Ex~K}\left(\mathrm{cmol} \mathrm{kg}^{-1}\right)$ & 0.31 & 0.02 & 0.40 & 0.03 & -2.47 & $0.045^{*}$ \\
\hline $\operatorname{Ex~Mg}\left(\mathrm{cmol} \mathrm{kg}^{-1}\right)$ & 0.63 & 0.19 & 0.70 & 0.27 & -1.33 & 0.14 \\
\hline $\mathrm{Ex} \mathrm{Na}\left(\mathrm{cmol} \mathrm{kg}^{-1}\right)$ & 0.56 & 0.10 & 0.40 & 0.11 & 0.86 & 0.23 \\
\hline Avail $\mathrm{P}\left(\mathrm{mgP} \mathrm{kg}^{-1}\right)$ & 250 & 98,184 & 418 & 122,524 & -5.04 & $0.015^{*}$ \\
\hline
\end{tabular}

Note. $\mathrm{EC}=$ Electrical conductivity; $\mathrm{OM}=$ Organic matter Walkley and Black method; TOC $=$ Total organic carbon Combustion method; Total $\mathrm{N}=$ Total nitrogen; $\mathrm{CEC}=$ Cation exchange capacity; Ex $\mathrm{Ca}, \mathrm{K}, \mathrm{Mg}, \mathrm{Na}=$ Exchangeable calcium, potassium, magnesium, sodium; Avail $\mathrm{P}=$ Available phosphorus.

$*$ = Significant at 0.05 .

\subsection{Soil Physical Properties}

All studied soils are sandy with a low water holding capacity (Table 8). Biochar application increases soil water holding capacity at FC by $1.3-1.7 \%$. Plant available water content of biochar-amended soils increased (by 0.8 to 2.4\%) (Table 8). Biochar application slightly reduced bulk density because biochar is less dense than soil minerals and also because biochar improves soil structure. Biochar application did not systematically affect saturated hydraulic conductivity (Table 8).

Paired differences of physical properties of unamended and biochar-amended soils are shown in Table 11. Field capacity, plant available water, water-stable aggregate-size fractions $(>2,2-1,0.25-0.1$ and $<0.1 \mathrm{~mm})$, median 
aggregate size and aggregate stability were significantly different according to paired t-test at $\mathrm{p}<0.05$. Special attention has been paid to evaluate the effects of biochar on the formation and protection of soil aggregates. Soil aggregate stability is a key indicator of soil structure. Biochar application increased the average size of aggregates and increased wet aggregate stability by 6 to 25\% (Table 9). Biochar enhances soil aggregation by providing organic binding agents and stimulates growth of fungi that produce abundant hyphae that bind to other soil particles (Blanco-Canqui, 2017).

Table 11. Paired sample t-test for physical properties of unamended and biochar-amended soils

\begin{tabular}{|c|c|c|c|c|c|c|c|}
\hline \multirow{3}{*}{ Parameter } & & \multicolumn{4}{|c|}{ Paired differences } & \multirow{3}{*}{$\mathrm{t}$} & \multirow{3}{*}{$\mathrm{P}$} \\
\hline & & \multicolumn{2}{|c|}{ Unamended soil } & \multicolumn{2}{|c|}{ Biochar-amended soil } & & \\
\hline & & $\bar{X}$ & S.D. & $\bar{X}$ & S.D. & & \\
\hline \multirow{3}{*}{ Water content ( $\%$ by weight $)$} & $\mathrm{FC} 1 / 3 \mathrm{~atm}$ & 7.68 & 7.87 & 9.70 & 9.82 & -3.81 & $0.016^{*}$ \\
\hline & PWP 15 atm & 3.03 & 1.57 & 3.58 & 1.91 & -1.76 & 0.099 \\
\hline & PAW & 4.65 & 2.43 & 6.13 & 3.45 & -4.06 & $0.014 *$ \\
\hline \multicolumn{2}{|l|}{ Bulk density $\left(\mathrm{g} \mathrm{cm}^{-3}\right)$} & 1.42 & 0.02 & 1.36 & 0.01 & 1.65 & 0.099 \\
\hline \multicolumn{2}{|l|}{ Ksat $\left(\mathrm{cm} \mathrm{hr}^{-1}\right)$} & 35 & 454 & 37 & 588 & -0.38 & 0.36 \\
\hline \multirow{6}{*}{$\begin{array}{l}\text { Water-stable aggregate-size } \\
\text { fractions }(\%)\end{array}$} & $>2 \mathrm{~mm}$ & 7 & 256 & 25 & 119 & -2.36 & $0.0496^{*}$ \\
\hline & $2-1 \mathrm{~mm}$ & 8 & 24 & 12 & 33 & -4.33 & $0.011 *$ \\
\hline & $1-0.5 \mathrm{~mm}$ & 14 & 63 & 13 & 37 & 1.13 & 0.17 \\
\hline & $0.5-0.25 \mathrm{~mm}$ & 20 & 44 & 16 & 9 & 1.43 & 0.12 \\
\hline & $0.25-0.1 \mathrm{~mm}$ & 26 & 83 & 18 & 98 & 2.60 & $0.040 *$ \\
\hline & $<0.1 \mathrm{~mm}$ & 24 & 68 & 17 & 106 & 5.71 & $0.005 *$ \\
\hline \multicolumn{2}{|l|}{ Median aggregate size $(\mathrm{mm})$} & 0.57 & 0.04 & 1.05 & 0.23 & -2.73 & $0.036^{*}$ \\
\hline \multicolumn{2}{|l|}{ Aggregate stability (\%) } & 50 & 176 & 65 & 355 & -3.54 & $0.019 *$ \\
\hline
\end{tabular}

Note. $\mathrm{FC}=$ Field capacity; $\mathrm{PWP}=$ Permanent wilting point, $\mathrm{PAW}=$ Plant available water.

$*=$ Significant at 0.05 .

\subsection{Soil-Biochar-Microbe Associations}

Crystalline minerals present in biochar contain important nutrients including phosphorus, potassium and calcium (Figures 1 and 2). These minerals are a food source for soil microorganisms making biochar a focus for microbial growth in soil (Lehmann et al., 2011). Biochar provides an excellent habitat for fungi and bacteria because of its porous structure that protects microorganisms and retains water in pores (Figure 2c) (Steinbeiss et al., 2009). Biochar grains become the nuclei of aggregates (Figures 3 to 4). Optical micrographs under plane polarized light demonstrated that the unamended sandy soil (control) consists mostly of single quartz grains including runiquartz (Figure 3a) whereas biochar-amended sandy soil also contains biochar grains surrounded by soil particles forming soil aggregates (Figure 3b). Biochar is mostly retained in aggregates by the action of fungal hyphae (Figure 4). Microorganisms proliferate in biochar as they extract phosphorus, potassium, calcium and other nutrients with fungi hyphae extending into the soil and holding biochar and soil particles together creating soil aggregates (Figure 4). Busscher et al. $(2010,2011)$ found that biochar did not affect aggregation in a coarse-textured soil possibly due to the low OM and clay contents of their soil. Several authors have reported that coarse-textured soils (e.g., sand to sandy loam) with low SOM contents need to be co-amended with biochar and organic residues to promote soil aggregation (Busscher et al., 2010, 2011; Awad et al., 2013; Khademalrasoul et al., 2014). In this study, biochars were capable of improving soil aggregation in coarse-textured soils with quite low organic matter contents despite farmers following organic agriculture methods. There is a close positive relationship between aggregate size and aggregate stability (Figure 5). Clearly soil physical properties are strongly affected by the capacity of biochar to enhance the extent and quality of soil aggregation. 

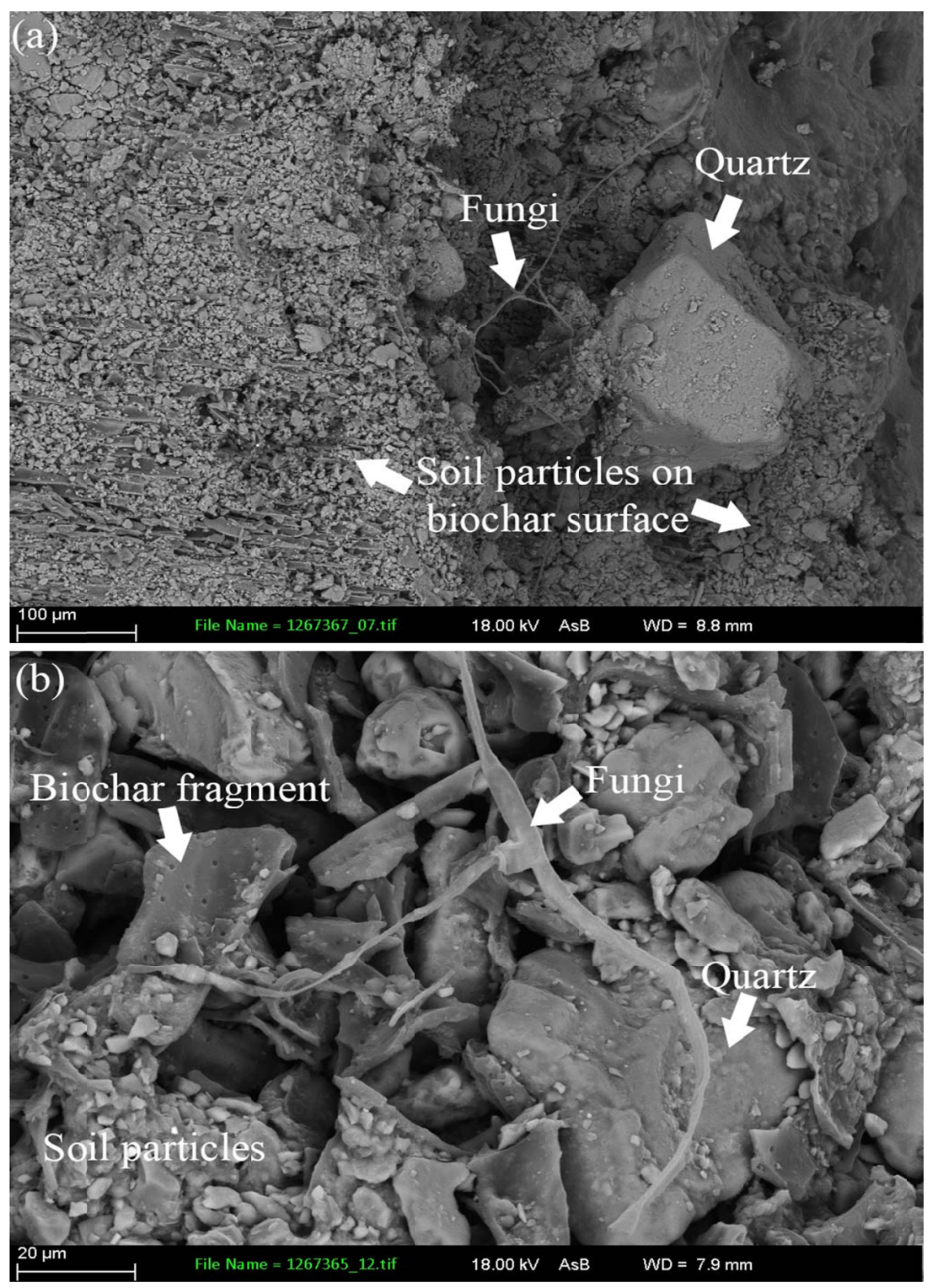

Figure 4. Scanning electron micrographs of the structure of soil aggregates. (a) showing the surface of a biochar grain from Chonburi containing abundant hyphae and attached soil particles, and (b) aggregate from Chainat soil showing the ramification of fungal hyphae through soil particles outside biochar fragments

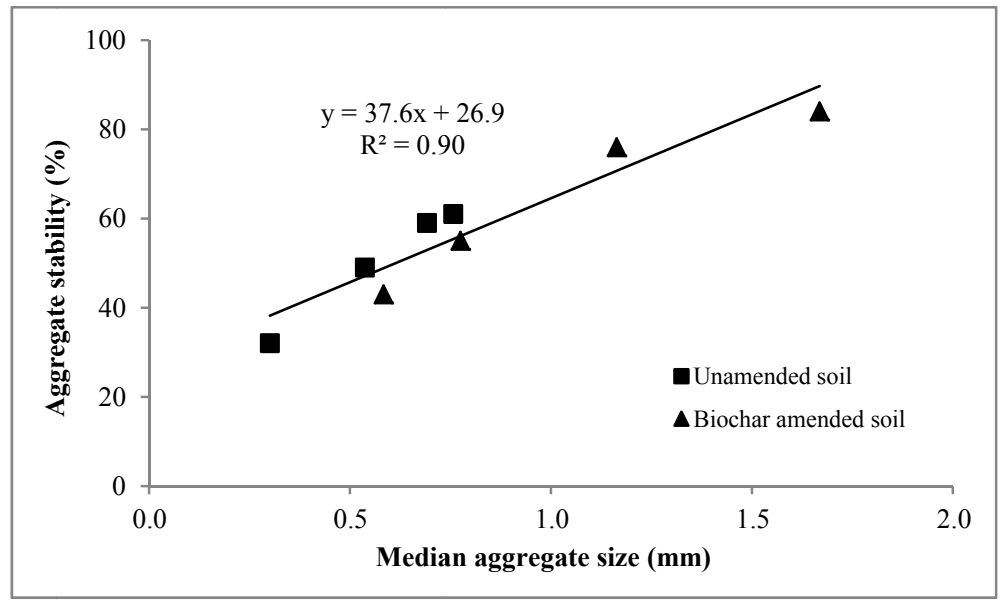

Figure 5. Aggregate stability versus median aggregate size 


\section{Discussion}

\subsection{Biochar Characteristics}

The highly porous nature of biochar results from retention of the cell wall structure of the biomass feedstock (Yadav et al., 2018). These studied biochars contain varying concentrations of plant elements (Tables 4 to 6) in the forms of crystalline and non-crystalline minerals (Figures 1 and 2). The fertilizer efficiency of plant nutrients in biochar is highly dependent on the type of feedstock. Based on elemental concentrations and the solubility of elements in biochar, durian shell biochar can be used as a $\mathrm{K}$ fertilizer. Wood biochars can be used as a liming agent. Clearly, biochars from the different feedstocks had different properties.

\subsection{Soil Chemical Characteristics}

Biochar application may improve the soil fertility status of coarse textured soils, especially soil OC, CEC, available P, exchangeable K, Ca, Mg (Chan et al., 2007; Sukartono et al., 2011) as biochar contains available nutrients (Sohi et al., 2009). In our case, CEC, exchangeable K and available $\mathrm{P}$ of biochar-amended soils were higher than for unamended soils whereas adding biochar into sandy soils did not affect $\mathrm{pH}, \mathrm{EC}, \mathrm{OM}, \mathrm{TOC}$, total $\mathrm{N}$ and exchangeable $\mathrm{Ca}, \mathrm{Mg}$ and $\mathrm{Na}$.

Biochar application resulted in no significant change of soil $\mathrm{pH}$ as was also observed by Adekiya et al., 2020 who recognized that there were no significant differences in soil $\mathrm{pH}$ values for additions of 20 and $30 \mathrm{tha}^{-1}$ biochar. It is probable that calcium in biochars of this study was contained mostly in calcite which dissolves slowly in water although other studies have concluded that soil $\mathrm{pH}$ increased after biochar was mixed into the soil (Lehmann et al., 2003; Rodriguez et al., 2009; Major et al., 2010; Masulili et al., 2010).

The increase in extractable cations in biochar-amended soil improved soil fertility especially for potassium. Our results illustrate that biochar significantly increased $\mathrm{CEC}$, exchangeable $\mathrm{K}$ and available $\mathrm{P}(\mathrm{P}<0.05)$ but the differences between total carbon and organic matter contents of biochar-amended soils and unamended soil were not significant. Biochar-amended soils have significantly higher CEC than unamended soils due to the presence of cation exchange sites on the surface of biochar and its large surface area (Adekiya et al., 2020). CEC of unamended and biochar-amended soils were less than $10 \mathrm{cmol} \mathrm{kg}^{-1}$ corresponding to low amounts of organic carbon and clay in the soil. The higher exchangeable potassium and available phosphorus values of biochar-amended soils are due to the crystalline and non-crystalline minerals on the biochar surface and inside the biochar structure. These minerals dissolve and release nutrients to soil solution. Exchangeable K significantly increased with biochar application to soil so evidently biochar can be a source of potassium in soil fertility management (Ghorbani \& Amirahmadi, 2018). The P availability of the soil increased after applying biochar due to the high $\mathrm{P}$ concentration in some biochars.

\subsection{Soil Physical Properties}

The results revealed that biochar application could improve sandy soil quality and significantly affect soil physical properties. Biochar improved field capacity, plant available water, water-stable aggregate size fractions $(>1 \mathrm{~mm}$ and $<0.25 \mathrm{~mm}$ ) but no significant difference was observed in bulk density and hydraulic conductivity which was similar to results of Laird et al. (2010). Numerous studies have indicated that biochar application could reduce bulk density (Chan \& Xu, 2009; Downie et al., 2009, Jien \& Wang, 2013; Hseu et al., 2014; Barus, 2016; Głąb et al., 2016; Blanco-Canqui, 2017). For this study, the bulk density of biochar-amend soil is slightly lower than unamended soils but the difference was not significant which was similarly reported by Abrishamkesh et al. (2015). Although, biochar is a porous material with low density (Yadav et al., 2018), this study has shown that biochar application did not affect bulk density and hydraulic conductivity. Probably these biochar application rates were not large enough to reduce bulk density and hydraulic conductivity (Mukherjee \& Lal, 2013; Abujabhah et al., 2016). The biochar application rates in this study range from 10 to $20 \mathrm{tha}^{-1}$ each year corresponding to the suggestion of a minimal rate of $10 \mathrm{tha}^{-1}$ (Dariah et al., 2010); however, Adekiya et al. (2020) found that an application rate of $30 \mathrm{t} \mathrm{ha}^{-1}$ biochar was required to reduce the bulk density of a tropical sandy loam Alfisols. Even larger amounts of biochar may be needed to make significant changes to some soil physical properties (Blanco-Canqui, 2017).

Soil physical properties were dependent not only on the biochar application rate but also on its particle size (Głąb et al., 2016). Biochar acts as a nucleus for soil aggregation. The average biochar particle size in this study is less than $2 \mathrm{~mm}$. The micromorphological observations of the biochar-amended soils illustrate the rearrangement of soil particles onto biochar surface with consequent soil aggregate formation. Applying biochar into sandy soils created more macroaggregates. Our study showed that the percentage of water-stable aggregate in size fractions (> 2 and 2-1 $\mathrm{mm}$ ) increased whereas the percentage of water-stable aggregates in the size 
fraction $(<0.25 \mathrm{~mm} \mathrm{~mm})$ decreased. Similarly, Sun and $\mathrm{Lu}$ (2014) reported that application of biochar significantly enhanced the formation of 5-2 and $0.25-0.5 \mathrm{~mm}$ macroaggregates in a clayey soil relative to the control treatment, while the $<0.25-\mathrm{cm}$ microaggregate fraction decreased with biochar additions. Burns (2014) carried out a similar study on a very sandy soil in South Western Australia where addition of $100 \mathrm{t} \mathrm{ha}^{-1}$ of wheat straw biochar increased the abundance of water stable aggregates from 50 to $61 \%$ of the soil over 3 years.

Regarding increases of field capacity and plant available water content in this study, the increases in median aggregate size of macroaggregates might be the cause. Larger aggregates retain more water than smaller aggregates because of intraaggregate pores (Liu et al., 2012). Biochar application directly increased the water holding capacity due to the inner surface area of the biochar and indirectly increased the water holding capacity by facilitating the formation of soil aggregates and macropores (Lei \& Zhang, 2013). Similar conclusions hold for the effect of biochar application on the water content at field capacity, permanent wilting point and plant available water content in sandy soils (Glaser et al., 2002; Downie et al., 2009; Laird et al., 2010; Bass et al., 2016; Barus, 2016). Tryon (1948) reported no significant effect of biochar application on plant available water of a loamy soil but there was a significant increase for a sandy soil. Bass et al. (2016) demonstrated that biochar application of $10 \mathrm{tha}^{-1}$ significantly increased soil water content compared to control. Application of biochar to sandy soil at $10 \mathrm{tha}^{-1}$ increased water use efficiency by 6 percent (Yadav et al., 2018). Increasing plant available water of biochar amended soils indicates that biochar application to agricultural land could contribute to the reduction of irrigation frequency (Blanco-Canqui, 2017).

\subsection{Soil-Biochar-Microbe Associations}

The microstructures of the biochar-amended soils indicate that soil particles especially clay are adsorbed on the biochar surface. The soil particles rearrange when the surfaces of clay and biochar interact forming microaggregates and combining with other soil-biochar complexes to form macroaggregates. Macroaggregate formation was an important factor in maintaining soil porosity and was a result of the increase in microbial activity in and adjacent to biochar grains (Barus, 2016).

Biochar application affects soil fauna and microorganism activities (Lehmann et al., 2011). Biochar properties may enhance soil microbial communities and create microenvironments that encourage microbial colonization as it is a porous material which is a good habitat for microbes (Sohi et al., 2009). Soils amended with biochar experience increases in soil microbes, earthworms, or other soil fauna particularly fungi promotion (Steinbeiss et al., 2009). Biochar acts as a refuge for soil microorganisms and adheres to soil particles creating soil aggregates. Soil aggregation is an important mechanism for stabilization of soil organic matter (Spohn \& Giani, 2011). Soil particles are bound together into microaggregates due to persistent binding agents. These microaggregates, in turn, build macroaggregates due to transient and temporary organic binding agents like polysaccharides, roots, and fungal hyphae (Tisdall \& Oades, 1982). Biochar is a food source and habitat for fungi that extend hypha out of biochar particles and which act as an organic binding agent.

\section{Conclusions}

Biochar was added by farmers to sandy soils with the goal of improving soil properties. The results indicated that applying large amounts of biochar to sandy soils for more than 3 years significantly increased some plant nutrients, cation exchange capacity, aggregation, soil aggregate stability and available water content. Applying biochar could redistribute soil particles increasing soil aggregate stability and biochar grains also are a potential habitat and a food source for microorganisms enhancing the microbial abundance in soil. In particular, biochar application increased the number of water-stable aggregates consisting of soil-biochar-microbe associations. Fungal hyphae, feeding in biochar, can act as a binding agent for soil particles. Fungal hyphae proliferate from biochar grains throughout the soil with a dense mesh of hyphae providing strength to soil aggregates. Fungi also exude organic compounds that will adhere to soil particles providing additional strength (Chenu \& Stotzky, 2002). The presence of biochar within soil aggregates can physically protect biochar particles in aggregates from decomposers. Consequently, aggregate formation due to the presence of biochar particles could enhance the storage of organic carbon in soils. Increasing soil aggregate stability improved field capacity and plant available water content. Clearly, biochar application can improve soil physicochemical properties. Biochar should gain acceptance as a long-term soil amendment for tropical sandy soils.

\section{References}

Abrishamkesh, S., Gorji, M., Asadi, H., Bagheri-Marandi, G., \& Pourbabaee, A. J. P. (2015). Effects of rice husk biochar application on the properties of alkaline soil and lentil growth. Plant Soil and Environment, 61, 475-482. https://doi.org/10.17221/117/2015-PSE 
Abujabhah, I. S., Doyle, R., Bound, S. A., \& Bowman, J. P. (2016). The effect of biochar loading rates on soil fertility, soil biomass, potential nitrification, and soil community metabolic profiles in three different soils. Journal of Soil and Sediments, 16, 2211-2222. https://doi.org/10.1007/s11368-016-1411-8

Adekiya, A. O., Agbede, T. M., Olayanju, A., Ejue, W. S., Adekanye, T. A., Adenusi, T. T., \& Ayeni, J. F. (2020). Effect of biochar on soil properties, soil loss, and cocoyam yield on a tropical sandy loam Alfisol. The Scientific World Journal, 2020, 1-9. https://doi.org/10.1155/2020/9391630

Andry, H., Yamamoto, T., Irie, T., Moritani, S., Inoue, M., \& Fujiyama, H. (2009). Water retention, hydraulic conductivity of hydrophilic polymers in sandy soil as affected by temperature and water quality. Journal of Hydrology, 373, 177-183. https://doi.org/10.1016/j.jhydrol.2009.04.020

Awad, Y. M., Blagodatskaya, E., Ok, Y. S., \& Kuzyakov, Y. (2013). Effects of polyacrylamide, biopolymer and biochar on the decomposition of 14C-labelled maize residues and on their stabilization in soil aggregates. European Journal of Soil Science, 64, 488-499. https://doi.org/10.1111/ejss.12034

Baiamonte, G., De Pasquale, C., Marsala, V., Cimò, G., Alonzo, G., Crescimanno, G., \& Conte, P. (2015). Structure alteration of a sandy-clay soil by biochar amendments. Journal of Soils and Sediments, 15, 816-824. https://doi.org/10.1007/s11368-014-0960-y

Barus, J. (2016). Utilization of crops residues as compost and biochar for improving soil physical properties and upland rice productivity. Journal of Degraded and Mining Lands Management, 3, 2502-2458. https://doi.org/10.15243/jdmlm.2016.034.631

Bass, A. M., Bird, M. I., Kay, G., \& Muirhead, B. (2016). Soil properties, greenhouse gas emissions and crop yield under compost, biochar and co-composted biochar in two tropical agronomic systems. Science of the Total Environment, 550, 459-470. https://doi.org/10.1016/j.scitotenv.2016.01.143

Blanco-Canqui, H. (2017). Biochar and soil physical properties. Soil Science Society of America Journal, 81, 687-711. https://doi.org/10.2136/sssaj2017.01.0017

Bruand, A., Hartmann, C., \& Lesturgez, G. (2005). Physical properties of tropical sandy soils: A large range of behaviours. Proceedings of Management of Tropical Sandy Soils for Sustainable Agriculture: A Holistic Approach for Sustainable Development of Problem Soils in the Tropics, 148-159. Retrieved from https://hal-insu.archives-ouvertes.fr/hal-00079666

Burns, K. J. (2014). The Effects of Biochar Additions on Soil Structure and Changes to Aged Biochar Particles in Soil (MSc Thesis, University of Western Australia, Australia).

Burt, R. (2004). Soil Survey Laboratory Methods Manual. Soil Survey Investigations Report No. 42, Version 4.0. Natural Resources Conservation Service, US Department of Agriculture, Washington, DC. Retrieved from https://books.google.co.th/books?id=JIp8ngEACAAJ

Busscher, W. J., Novak, J. M., \& Ahmedna, M. (2011). Physical effects of organic matter amendment of a southeastern US coastal loamy sand. Soil Science, 176, 661-667. https://doi.org/10.1097/SS.0b013e $3182357 \mathrm{ca} 9$

Busscher, W. J., Novak, J. M., Evans, D. E., Watts, D. W., Niandou, M., \& Ahmedna, M. (2010). Influence of pecan biochar on physical properties of a Norfolk loamy sand. Soil Science, 175, 10-14. https://doi.org/ $10.1097 / \mathrm{SS} .0 \mathrm{~b} 013 \mathrm{e} 3181 \mathrm{cb} 7 \mathrm{f} 46$

Chan, K. Y., \& Xu, Z. (2009). Biochar: Nutrient properties and their enhancement. In J. Lehmann \& S. Joseph (Eds.), Biochar for Environmental Management: Science and Technology (pp. 85-106). Earthscan, London, UK.

Chan, K. Y., Van Zwieten, L., Meszaros, I., Downie, A., \& Joseph, S. (2007). Agronomic values of green waste biochar as a soil amendment. Australian Journal of Soil Research, 45, 629-634. https://doi.org/10.1071/ SR07109

Chenu, C., \& Stotzky, G. (2002). Interactions between microorganisms and soil particles: An overview. In P. M. Huang, J. M. Bollag, \& N. Senesi (Eds.), Interactions between Soil Particles and Microorganisms: Impact on the Terrestrial Ecosystem (pp. 4-29). John Wiley \& Sons, Ltd.

Cox, M. R., \& Budhu, M. (2008). A practical approach to grain shape quantification. Engineering Geology, 96, 1-16. https://doi.org/10.1016/j.enggeo.2007.05.005 
Crane-Droesch, A., Abiven, S., Jeffery, S., \& Torn, M. S. (2013). Heterogeneous global crop yield response to biochar: A meta-regression analysis. Environmental Research Letters, 8, 1-8. https://doi.org/10.1088/ $1748-9326 / 8 / 4 / 044049$

Dariah, A., \& Sutono, N. N. L. (2010). Penggunaan pembenah tanah organik dan mineral untuk perbaikan kualitas tanah Typic Kanhapludults Tamanbogo, Lampung. Jurnal Tanah dan Iklim, 31, 1-10. https://doi.org/10.21082/jsdl.v9n2.2015.\%25p

Downie, A., Crosky, A., \& Munroe, P. (2009). Physical properties of biochar. In J. Lehmann \& S. Joseph (Eds.), Biochar for Environmental Management: Science and Technology (pp. 13-32). Earthscan, London, UK.

Fellet, G., Marchiol, L., Delle Vedove, G., \& Peressotti, A. (2011). Application of biochar on mine tailings: Effects and perspectives for land reclamation. Chemosphere, 83, 1262-1267. https://doi.org/10.1016/ j.chemosphere.2011.03.053

Fromm, J. (2010) Wood formation of trees in relation to potassium and calcium nutrition. Tree Physiology, 30, 1140-1147. https://doi.org/10.1093/treephys/tpq024

Ghorbani, M., \& Amirahmadi, E. (2018). Effect of rice husk Biochar (RHB) on some of chemical properties of an acidic soil and the absorption of some nutrients. Journal of Applied Sciences and Environmental Management, 22, 313-317. https://doi.org/10.4314/jasem.v22i3.4

Głąb, T., Palmowska, J., Zaleski, T., \& Gondek, K. (2016). Effect of biochar application on soil hydrological properties and physical quality of sandy soil. Geoderma, 281, 11-20. https://doi.org/10.1016/j.geoderma. 2016.06.028

Glaser, B., Lehmann, J., \& Zech, W. (2002). Ameliorating physical and chemical properties of highly weathered soils in the tropics with charcoal-A review. Biology and Fertility of Soils, 35, 219-230. https://doi.org/ 10.1007/s00374-002-0466-4

Gondek, K., Mierzwa-Hersztek, M., Kopeć, M., Sikora, J., Głąb, T., \& Szczurowska, K. (2019). Influence of biochar application on reduced acidification of sandy soil, increased cation exchange capacity, and the content of available forms of K, Mg, and P. Polish Journal of Environmental Studies, 28, 103-111. https://doi.org/10.15244/pjoes/81688

Hseu, Z. Y., Jien, S. H., Chien, W. H., \& Liou, R. C. (2014). Impacts of biochar on physical properties and erosion potential of a mudstone slope land soil. The Scientific World Journal, 2014, 1-10. https://doi.org/ $10.1155 / 2014 / 602197$

Huang, J., \& Hartemink, A. E. (2020). Soil and environmental issues in sandy soils. Earth-Science Reviews, 208, 1-22. https://doi.org/10.1016/j.earscirev.2020.103295

Jeffery, S., Verheijen, F. G., van der Velde, M., \& Bastos, A. C. (2011). A quantitative review of the effects of biochar application to soils on crop productivity using meta-analysis. Agriculture, Ecosystems \& Environment, 144, 175-187. https://doi.org/10.1016/j.agee.2011.08.015

Jien, S. H., \& Wang, C. S. (2013). Effects of biochar on soil properties and erosion potential in a highly weathered soil. Catena, 110, 225-233. https://doi.org/10.1016/j.catena.2013.06.021

Kemper, W., \& Rosenau, R. (1986). Aggregate stability and size distribution. Methods of Soil Analysis: Part 1 Physical and Mineralogical Methods (Vol. 5, pp. 425-442). ASA, Madison, WI, USA. https://doi.org/ 10.2136/sssabookser5.1.2ed.c17

Khademalrasoul, A., Naveed, M., Heckrath, G., Kumari, K., de Jonge, L. W., Elsgaard, L., ... Iversen, B. V. (2014). Biochar effects on soil aggregate properties under no-till maize. Soil Science, 179, 273-283. https://doi.org/10.1097/SS.0000000000000069

Laird, D., Fleming, P., Wang, B., Horton, R., \& Karlen, D. (2010). Biochar impact on nutrient leaching from a Midwestern agricultural soil. Geoderma, 158, 436-442. https://doi.org/10.1016/j.geoderma.2010.05.012

Lehmann, J. (2007). Bio-energy in the black. Frontiers in Ecology and the Environment, 5, $381-387$. https://doi.org/10.1890/1540-9295(2007)5[381:BITB]2.0.CO;2

Lehmann, J., da Silva, J. P., Steiner, C., Nehls, T., Zech, W., \& Glaser, B. (2003). Nutrient availability and leaching in an archaeological Anthrosol and a Ferralsol of the Central Amazon basin: Fertilizer, manure and charcoal amendments. Plant and Soil, 249, 343-357. https://doi.org/10.1023/A:1022833116184 
Lehmann, J., Rillig, M. C., Thies, J., Masiello, C. A., Hockaday, W. C., \& Crowley, D. (2011). Biochar effects on soil biota-A review. Soil Biology and Biochemistry, 43, 1812-1836. https://doi.org/10.1016/j.soilbio. 2011.04 .022

Lei, O., \& Zhang, R. (2013). Effects of biochars derived from different feedstocks and pyrolysis temperatures on soil physical and hydraulic properties. Journal of Soils and Sediments, 13, 1561-1572. https://doi.org/ 10.1007/s11368-013-0738-7

Liu, X. H., Han, F. P., \& Zhang, X. C. (2012). Effect of biochar on soil aggregates in the Loess Plateau: Results from incubation experiments. International Journal of Agriculture and Biology, 14(6), 975-979. https://doi.org/10.1155/2014/602197

Major, J., Rondon, M., Molina, D., Riha, S. J., \& Lehmann, J. (2010). Maize yield and nutrition during 4 years after biochar application to a Colombian Savanna Oxisol. Plant and Soil, 333, 117-128. https://doi.org/ $10.1007 / \mathrm{s} 11104-010-0327-0$

Masulili, A., Utomo, W. H., \& Syechfani, M.J. (2010). Rice husk biochar for rice based cropping system in acid soil 1. The characteristics of rice husk biochar and its influence on the properties of acid sulfate soils and rice growth in West Kalimantan, Indonesia. Journal of Agriculture Science, 2, 39-47. https://doi.org/ 10.5539/jas.v2n1p39

Mekuria, W., \& Noble, A. (2013). The role of biochar in ameliorating disturbed soils and sequestering soil carbon in tropical agricultural production systems. Applied and Environmental Soil Science, 2013, 1-10. https://doi.org/10.1155/2013/354965

Mukherjee, A., \& Lal, R. (2013). Biochar impacts on soil physical properties and greenhouse gas emissions. Agronomy, 3, 313-339. https://doi.org/10.3390/agronomy3020313

Prakongkep, N., Gilkes, R. J., \& Wiriyakitnateekul, W. (2015). Forms and solubility of plant nutrient elements in tropical plant waste biochars. Journal of Plant Nutrition and Soil Science, 178, 732-740. https://doi.org/ 10.1002/jpln.201500001

Rodríguez, L., Salazar, P., \& Preston, T. R. (2009). Effect of biochar and biodigester effluent on growth of maize in acid soils. Livestock Research for Rural Development, 21(7), 1-11. Retrieved from http://www.lrrd.org/ $\operatorname{lrrd} 21 / 7 / \operatorname{rodr} 21110$. htm

Sohi, S., Loez-Capel, E., Krull, E., \& Bol, R. (2009). Biochar's Roles in Soil and Climate Change: A Review of Research Needs (Report 05/09, p. 64). CSIRO Land and Water Science. https://oi.org/10.4225/08/ 58597219a199a

Sorrenti, G., \& Toselli, M. (2016). Soil leaching as affected by the amendment with biochar and compost. Agriculture, Ecosystems \& Environment, 226, 56-64. https://doi.org/10.1016/j.agee.2016.04.024

Spohn, M., \& Giani, L. (2011). Impacts of land use change on soil aggregation and aggregate stabilizing compounds as dependent on time. Soil Biology and Biochemistry, 43, 1081-1088. https://doi.org/10.1016/ j.soilbio.2011.01.029

Steinbeiss, S., Gleixner, G., \& Antonietti, M. (2009). Effect of biochar amendment on soil carbon balance and soil microbial activity. Soil Biology and Biochemistry, 41, 1301-1310. https://doi.org/10.1016/j.soilbio. 2009.03.016

Sukartono, Utomo, W. H., Kusauma, Z., \& Nugroho, W. H. (2011). Soil fertility status, nutrient uptake and maize (Zea mays L.) yield following biochar and cattle manure application on sandy soils of Lombok, Indonesia. Journal of Tropical Agriculture, 49(1-2), 47-52. Retrieved from https://www.phytojournal.com/archives/ 2018/vol7issue4/PartB/7-3-678-801.pdf

Sun, F., \& Lu, S. (2014). Biochars improve aggregate stability, water retention, and pore-space properties of clayey soil. Journal of Plant Nutrition and Soil Science, 177, 26-33. https://doi.org/10.1002/jpln.201200639

Tisdall, J. M., \& Oades, J. M. (1982). Organic matter and water-stable aggregates in soils. Journal of Soil Science, 33, 141-163. https://doi.org/10.1111/j.1365-2389.1982.tb01755.x

Tryon, E. (1948). Effect of charcoal on certain physical, chemical, and biological properties of forest soils. Ecological Society of America, 18(1), 81-115. https://doi.org/10.2307/1948629

Wang, L., Butterly, C., Wang, Y., Herath, H., Xi, Y., \& Xiao, X. (2014). Effect of crop residue biochar on soil acidity amelioration in strongly acidic tea garden soils. Soil Use and Management, 30, 119-128. https://doi.org/10.1111/sum.12096 
Yadav, N. K., Kumar, V., Sharma, K., Choudhary, R. S., Butter, T. S., Singh, G., ... Kumar, R. (2018). Biochar and their impacts on soil properties and crop productivity: A review. Journal of Pharmacognosy and Phytochemistry, 7, 49-54. Retrieved from https://www.phytojournal.com/archives/2018/vol7issue4/PartB/ 7-3-678-801.pdf

Yuan, J. H., Xu, R. K., Wang, N., \& Li, J. Y. (2011). Amendment of acid soils with crop residues and biochars. Pedosphere, 21, 302-308. https://doi.org/10.1016/S1002-0160(11)60130-6

Zhou, L., Liu, J., Zhao, B., Xue, A., \& Hao, G. (2016). Effects of soil amendment on soil characteristics and maize yield in Horqin sandy land. Earth and Environmental Science, 41, 1-12. https://oi.org/10.1088/ $1755-1315 / 41 / 1 / 012005$

\section{Copyrights}

Copyright for this article is retained by the author(s), with first publication rights granted to the journal.

This is an open-access article distributed under the terms and conditions of the Creative Commons Attribution license (http://creativecommons.org/licenses/by/4.0/). 